\title{
PENAMBAHAN TEPUNG DAUN SISIK NAGA (Drymoglosum pilloselloides) TERHADAP KECERNAAN IN VITRO KONSENTRAT BERBAHAN PAKAN FERMENTASI
}

\author{
Erwin Yulianto ${ }^{1}$, Andu Murlina Tasse ${ }^{2}$, Rahman $^{2}$ \\ ${ }^{1)}$ Alumnus Fakultas Peternakan UHO \\ ${ }^{2)}$ Staf Pengajar Fakultas Peternakan UHO \\ "e-mail : andimurlinatasse@gmail.com
}

\begin{abstract}
ABSTRAK
Penelitian bertujuan untuk mengetahui pengaruh penambahan tepung daun sisik naga (Drymoglosum pilloseloides) terhadap kecernaan in vitro konsentrat berbahan pakan fermentasi. Perlakuan terdiri atas konsentrat yang diberi penambahan tepung daun sisik naga $0 \%$ (R0), 0,05\% (R1), $0,1 \%$ (R2) dan $0,15 \%$ (R3). Rancangan percobaan yang digunakan yaitu rancangan acak lengkap (RAL) dengan 4 perlakuan dan 3 ulangan. Penelitian ini dilaksanakan selama empat minggu di Laboratorium Jurusan Peternakan Fakultas Peternakan Universitas Haluoleo. Rataan kadar air setiap perlakuan $15,50 \% \pm 2,56 \%$ (R0), $16,17 \% \pm 0,32 \%(\mathrm{R} 1), 17,80 \% \pm 1,57 \%$ (R2) dan 16,83\% \pm $1,58 \%$ (R3), kadar abu 25,90\% $\pm 0,72 \%$ (R0), $21,40 \% \pm 0,52 \%$ (R1), 20,07\% $\pm 0,25 \%$ (R2) dan $18,50 \% \pm 0,53 \%$ (R3), kecernaan bahan kering $81,33 \% \pm 1,00 \%$ (R0), $81,73 \% \pm 0,49 \%$ (R1), 82,27\% $\pm 0,91 \%(\mathrm{R} 2)$ dan $81,40 \% \pm 0,10 \%$ (R3), kecernaan bahan organik $81,70 \% \pm 1,31 \%(\mathrm{R} 0), 83,90 \% \pm$ $1,59 \%$ (R1), $83,17 \% \pm 0,90 \%$ (R2) dan $82,50 \% \pm 0,46 \%$ (R3). Hasil analisis ragam menunjukkan konsentrat dengan penambahan tepung daun sisik naga $0 \%, 0,05 \%, 0,10 \%$ dan $0,15 \%$ tidak berpengaruh nyata $(\mathrm{P}>0,05)$ terhadap kadar air, kecernaan bahan kering dan kecernaan bahan organik. Sedangkan konsentrat dengan penambahan tepung daun sisik naga $0 \%, 0,05 \%, 0,10 \%$ dan $0,15 \%$ berpengaruh sangat nyata $(\mathrm{P}<0,05)$ terhadap kadar abu. Kecernaan bahan kering dan bahan organik lebih tinggi dari kisaran normal yang layak diberikan kepada ternak. Oleh karena itu konsentrat dengan penambahan tepung daun sisik naga tidak menurunkan kecernaan bahan kering dan bahan organik secara in vitro.
\end{abstract}

Kata Kunci : daun sisik naga, pakan fermentasi, kecernaan bahan kering, bahan organik.

\begin{abstract}
This study aims to know the effect of addition of Drymoglosum pilloseloides flour on in vitro digestibility of consentrates made from fermentation feed. The treatments consist of concentrates ware added Drymoglosum pilloseloides flour $0 \%$ (R0), 0,05\% (R1), 0,1\% (R2), and $0,15 \%$ (R3). Experimental design was used completely randomized design (CRD) with 4 treatments and 3 replications. This study was conducted during four weeks in Animal Science Department, of Animal Science Faculty, of Haluoleo University. The average of water content of each treatment was $15,50 \% \pm 2,56 \%(\mathrm{R} 0), 16,17 \% \pm 0,32 \%(\mathrm{R} 1), 17,80 \% \pm 1,57 \%(\mathrm{R} 2)$ and $16,83 \% \pm 1,58 \%(\mathrm{R} 3)$, ash content was $25,90 \% \pm 0,72 \%$ (R0), $21,40 \% \pm 0,52 \%$ (R1), $20,07 \% \pm 0,25 \%$ (R2) and $18,50 \% \pm$ $0,53 \%$ (R3), dry matter digestibility was $81,33 \% \pm 1,00 \%$ (R0), $81,73 \% \pm 0,49 \%$ (R1), $82,27 \% \pm$ $0,91 \%$ (R2) and $81,40 \% \pm 0,10 \%$ (R3), organic matter digestibility was $81,70 \% \pm 1,31 \%$ (R0), $83,90 \% \pm 1,59 \%(\mathrm{R} 1), 83,17 \% \pm 0,90 \%(\mathrm{R} 2)$ and $82,50 \% \pm 0,46 \%$ (R3). The result of analysis of variance not showed that addition of Drymoglosum pilloseloides flour $0 \%, 0,05 \%, 0,10 \%$ and $0,15 \%$ significant effect $(\mathrm{P}>0,05)$ on water content, dry matter digestibility and organic matter digestibility. While concentrates with addition of Drymoglosum pilloseloides flour $0 \%, 0,05 \%, 0,10 \%$ and $0,15 \%$ significant effect $(\mathrm{P}<0,05)$ on ash content. Dry matter and organic matter digestibility were higher than normal range that usually be given to animal. Therefore concentrates with addition of Drymoglosum pilloseloides flour no decreased dry matter and dry organic digestibilities.
\end{abstract}

Key Words: Drymoglosum pilloseloides, fermented feed, dry matter digestibility

${ }^{*}$ Corresponding authors 


\section{PENDAHULUAN}

Daun sisik naga (Drymoglossum piloselloides Presl.) merupakan salah satu jenis tumbuhan yang termasuk dalam kelompok tumbuhan herbal, dan mengandung minyak atsiri, sterol/triterpen, fenol, flavonoid, tanin, dan gula. Disamping itu efek farmakologis tumbuhan ini dapat menghambat peradangan paru-paru pada manusia. Ruminansia dapat menderita penyakit paru-paru, padahal pengadaan obat-obatan tidak mudah dan harganya terkadang tidak dapat dijangkau oleh peternak terutama di pedesaan. Oleh karena itu, pemanfaatan daun sisik naga sebagai obat herbal untuk ternak khususnya ruminansia perlu dilakukan sebagai upaya pengadaan obat tradisional.

Penggunaan herbal pada ruminansia perlu pengujian kelayakan pemberiannya karena proses pencernaan ruminansia sangat spesifik karena keberadaan mikroba dalam rumen. Kondisi dalam rumen perlu diperhatikan agar proses pencernaan normal. Salah satu indikatornya adalah kecernaan.

Pakan fermentasi dapat diperoleh melalui fermentasi pakan dengan menggunakan cairan rumen. Selanjutnya berbagai pakan fermentasi diformulasi menjadi konsentrat. Konsentrat berbahan pakan fermentasi dapat digunakan untuk pakan ternak ruminansia, karena tidak mengganggu proses pencernaan dalam rumen yang ditunjukkan oleh kecernaan bahan kering dan bahan organik dalam kisaran normal ( Mizan, 2012 dan Sadariawan, 2013).

Kecernaan bahan kering menunjukkan proporsi bahan kering dari pakan yang dapat dicerna oleh mikroba dalam rumen. Sedangkan kecernaan bahan organik menunjukkan proporsi bahan organik dari pakan yang dapat dicerna oleh enzim kecernaan yang dihasilkan oleh mikroba rumen. Oleh karena itu, penelitian awal tentang pemanfaatan tepung daun sisik naga melalui penambahan dalam konsentrat perlu dilakukan untuk mengetahui nilai kecernaannya.

\section{MATERI DAN METODE}

Bahan penelitian yang disiapkan adalah dedak padi fermentasi, ampas sagu fermentasi, ampas tahu, $\mathrm{NaCl}_{2}, \mathrm{CaCO}_{3}$, cairan rumen dan tepung daun sisik naga (Drymoglossum pilloselloides Presl.) Bahan pakan dikeringkan dibawah sinar matahari. Selanjutnya bahan pakan dimasukan ke dalam wadah dan ditambah cairan rumen dengan perbandingan $3 \mathrm{~kg}$ bahan pakan dan 1 liter cairan rumen sapi kemudian wadah ditutup rapat, difermentasi selama 3 hari. Pakan fermentasi dikeringkan di bawah sinar matahari. Pakan siap diformulasi menjadi konsentrat

Konsentrat yang digunakan dalam penelitian yaitu konsentrat berbasis dedak fermentasi $60 \%$. Konsentrat perlakuan terdiri atas:

$\mathrm{R} 0=$ Konsentrat dedak fermentasi $60 \%$

$\mathrm{R} 1=$ Konsentrat dedak fermentasi $60 \%+$ $0,05 \%$ tepung daun sisik naga

$\mathrm{R} 2=$ Konsentrat dedak fermentasi $60 \%$ $+0,10 \%$ tepung daun sisik naga

R3 = Konsentrat dedak fermentasi $60 \%+$ $0,15 \%$ tepung daun sisik naga

Alat yang digunakan adalah timbangan analitik, oven, tanur, corong plastik, gelas ukur $100 \mathrm{ml}$ dan $1000 \mathrm{ml}$, hot plte, tabung reaksi, panci, termometer ruagan, kertas label, kantong plastik, spatula, stand biuret, Saringan dan sendok.

\section{a. Pembuatan Tepung Daun Sisik Naga}

Daun sisik naga segar

(Drymoglossum pilloselloides Presl.) dibersihkan dari kotoran yang menempel dan diptong-potong kecil kemudian dikeringkan dalam oven dengan suhu $60^{\circ} \mathrm{C}$. Daun sisik naga kering dihaluskan lalu diayak dengan menggunakan saringan sehingga menghasilkan tepung daun sisik naga. 


\section{b. Prosedur Pembuatan Pakan Fermentasi}

Bahan pakan dikeringkan di bawah sinar matahari. Selanjutnya bahan pakan dimasukan ke dalam wadah dan ditambah cairan rumen dengan perbandingan $3 \mathrm{~kg}$ bahan pakan dan 1 liter cairan rumen sapi kemudian wadah ditutup rapat, difermentasi selama 3 hari. Pakan fermentasi dikeringkan di bawah sinar matahari. Setelah kering pakan siap diformulasi menjadi konsentrat.

\section{c. Kecernaan Bahan Kering dan Bahan Organik Secara In Vitro}

Pengukuran kecernaan bahan kering dan bahan organik dilakukan dengan menggunakan metode Tilley dan Terry (1963), yang telah dimodifikasi dalam Tasse (2011). Sebanyak 1-2 gram konsentrat ditimbang, dimasukan dalam tabung reaksi dan ditambah dengan larutan saliva buatan sebanyak $12 \mathrm{ml}$ suhu $39{ }^{0} \mathrm{C}$ pH 6,5 - 6,9 dan $8 \mathrm{ml}$ cairan rumen. Selanjutnya, tabung reaksi ditutup dengan penutup karet dan difermentasi selama 3 jam pada suhu $39-40{ }^{\circ} \mathrm{C}$. Setelah fermentasi, campuran ransum, saliva buatan dan cairan rumen ditetesi larutan $\mathrm{HgCl}_{2}$ jenuh sebanyak $0,2 \mathrm{ml}$ untuk mematikan mikrobanya lalu disimpan pada suhu ruangan hingga terbentuk endapan. Selanjutnya hasil fermentasi disaring dengan kertas saring Whatman no. 41. Filtrat dikeringkan dalam oven pada suhu $105{ }^{0} \mathrm{C}$ selama 24 jam. Setelah kering, sampel ditimbang menggunakan timbangan digital lalu dimasukan dalam tanur pada suhu $400{ }^{0} \mathrm{C}$ selama 4 jam. $\mathrm{Abu}$ yang terbentuk ditimbang menggunakan timbangan digital.

\section{HASIL DAN PEMBAHASAN}

\section{A. Kadar Air}

Kadar air merupakan salah satu sifat fisik dari bahan yang menunjukan banyaknya air yang terkandung di dalam bahan. Kandungan air suatu bahan yang dapat dinyatakan berdasarkan berat basah atau berdasarkan berat kering. Rataan kadar air konsentrat berbahan pakan fermentasi yang diberi penambahan tepung daun sisik naga (Drymoglosum pilloselloides Presl.) secara in vitro dapat dilihat pada Tabel 1.

Tabel 1. Kadar Air Konsentrat

\begin{tabular}{cccccc}
\hline \multirow{2}{*}{ Ulangan } & \multicolumn{3}{c}{ Penambahan Tepung Daun Sisik Naga } & \multirow{2}{*}{ Total } \\
\cline { 2 - 5 } & $0 \%(\mathrm{R} 0)$ & $0,05 \%(\mathrm{R} 1)$ & $0,10 \%(\mathrm{R} 2)$ & $0,15 \%(\mathrm{R} 3)$ & \\
\hline 1 & 15,2 & 16,3 & 16,1 & 18,2 & 65,8 \\
\hline 2 & 18,1 & 15,8 & 18,1 & 15,1 & 67,1 \\
\hline 3 & 13,2 & 16,4 & 19,2 & 17,2 & 66 \\
\hline Total & 46,5 & 48,5 & 53,4 & 50,5 & 198,9 \\
\hline Rataan & $15,50 \pm 2,46$ & $16,17 \pm 0,32$ & $17,80 \pm 1,57$ & $16,83 \pm 1,58$ & 16,58 \\
\hline
\end{tabular}

Hasil analisis data menunjukkan kadar air konsentrat berbahan pakan fermentasi dengan penambahan tepung daun sisik naga tidak berpengaruh nyata $(\mathrm{P}>0,05)$ terhadap kadar air (tabel 1). Hal ini berarti kadar air dalam konsentrat tanpa penambahan tepung daun sisik naga $0 \%$ tidak berbeda nyata dengan konsentrat dengan penambahan tepung daun sisik naga $0,05 \%$, konsentrat dengan penambahan tepung daun sisik naga $0,10 \%$, dan konsentrat dengan penambahan tepung daun sisik naga $0,15 \%$ $(15,50 \%$ dibanding dengan $16,17 \%$, $17,80 \%$ dibanding dengan 16,83\%). Kadar air dalam konsentrat dengan penambahan tepung daun sisik naga $0,05 \%$ berbeda tidak nyata dengan konsentrat dengan penambahan tepung daun sisik naga $0,1 \%$, konsentrat dengan penambahan tepung 
daun sisik naga $0,15 \%(16,17 \%$ dibanding dengan $17,80 \%$ dan $16,83 \%$ ). Selanjutnya, kadar air konsentrat dengan penambahan tepung daun sisik naga $0,10 \%$ berbeda tidak nyata dengan konsentrat dengan penambahan tepung daun sisik naga $0,15 \%$ (17,80\% dibanding dengan $16,83 \%)$. Hal ini menunjukkan konsentrat dengan penambahan tepung daun sisik naga sampai pada taraf $0,15 \%$ dalam konsentrat tidak meningkatkan kadar air.

Rataan kadar air hasil penelitian $(16,58 \%)$ lebih tinggi dibanding dengan kadar air yang ditetapkan Badan Standarisasi Nasional tentang persyaratan pakan konsentrat sapi potong (SNI 3148.2:2009) (14\%). Namun demikian rataan kadar air hasil penelitian $(16,58 \%)$ lebih rendah dibanding dengan hasil penelitian Sulaeman (2001) bahwa rataan kadar air ransum yang menggunakan fermentasi kapang A. niger (18,08\%). Perbedaan hasil penelitian ini menunjukkan kadar air konsentrat berbahan pakan fermentasi yang ditambahkan tepung daun sisik naga
(Drymoglosum pilloselloides Presl.) lebih rendah dibanding dengan kadar air ransum yang menggunakan fermentasi kapang Aspergellus niger tanpa penambahan tepung daun sisik naga.

Perbedaan ini juga disebabkan konsentrat yang digunakan pada penelitian menggunakan pakan as fed, misalnya dedak padi fermentasi kering, ampas sagu fermentasi kering dan ampas tahu segar sehingga kadar air yang terukur tinggi.

B.

adar Abu Konsentrat

Kadar abu merupakan campuran dari komponen anorganik atau mineral yang terdapat pada suatu bahan. Kadar abu dapat menunjukan total mineral dalam suatu bahan. Rataan kadar abu konsentrat berbahan pakan fermentasi yang diberi penambahan tepung daun sisik naga (Drymoglosum pilloselloides Presl.) dapat dilihat pada tabel 2 .

Tabel 2. Kadar abu konsentrat

\begin{tabular}{cccccc}
\hline \multirow{2}{*}{ Ulangan } & \multicolumn{4}{c}{ Penambahan Tepung Daun Sisik Naga } & \multirow{2}{*}{ Total } \\
\cline { 2 - 5 } & $0 \%(\mathrm{R} 0)$ & $0,05 \%(\mathrm{R} 1)$ & $0,10 \%(\mathrm{R} 2)$ & $0,15 \%(\mathrm{R} 3)$ & \\
\hline 1 & 25.1 & 21.1 & 20.3 & 18.1 & 84.6 \\
\hline 2 & 26.1 & 22 & 19.8 & 19.1 & 87 \\
\hline 3 & 26.5 & 21.1 & 20.1 & 18.3 & 86 \\
\hline Total & 77.7 & 64.2 & 60.2 & 55.5 & 257.6 \\
\hline Rataan & $25.90 \pm 0,72^{\mathrm{d}}$ & $21.40 \pm 0,52^{\mathrm{c}}$ & $20.07 \pm 0,25^{\mathrm{b}}$ & $18.50 \pm 0,53^{\mathrm{a}}$ & 21,47 \\
\hline
\end{tabular}

Keterangan : Superskrip berbeda menunjukkan berbeda nyata $(\mathrm{P}<0,05)$

Hasil analisis data menunjukkan konsentrat berbahan pakan fermentasi dengan penambahan tepung daun sisik naga berpengaruh sangat nyata $(\mathrm{P}<0,05)$ terhadap kadar abu. Kadar abu konsentrat tanpa penambahan tepung daun sisik naga (0\%) lebih tinggi dibanding dengan konsentrat dengan penambahan tepung daun sisik naga $(0,05 \%, 0,10 \%$, dan $0,15 \%) \quad(25,90 \%$ dibanding dengan $21,40 \%$, 20,07\%, dan 18,50\%).
Sebaliknya, kadar abu konsentrat dengan penanambahan tepung daun sisik naga $0,05 \%$ lebih tinggi dibanding dengan konsentrat dengan penambahan tepung dauk sisik naga $0,10 \%$ dan $0,15 \%(21,40 \%$ dibanding dengan $20,07 \%$ dan $18,50 \%$ ) tetapi lebih rendah dibandingkan dengan konsentrat tanpa penambahan tepung daun sisik naga $(21,40 \%$ dibanding dengan $25,90 \%)$. Selanjutnya konsentrat dengan penambahan tepung daun sisik naga $0,1 \%$ 
lebih tinggi dibanding dengan konsentrat dengan penambahan tepung daun sisik naga $0,15 \% \quad(20,07 \%$ dibanding dengan $18,50 \%$ ) tetapi lebih rendah dibanding konsentrat tanpa penambahan tepung daun sisik naga dan konsentrat dengan penambahan tepung daun sisik naga $0,05 \%$. Kadar abu konsentrat dengan penambahan tepung daun sisik naga $0,15 \%$ lebih rendah dibanding dengan konsetrat dengan penambahan tepung daun sisik naga $0,10 \%, 0,05 \%$ dan $0 \%$. Hal ini menunjukkan penggunaan konsentrat berbahan pakan fermentasi dengan penambahan tepung daun sisik naga dapat menurunkan kandungan kadar abu dalam konsentrat.

Rataan kadar abu hasil penelitian $(21,47 \%)$ lebih tinggi dibandingkan dengan yang ditetapkan Badan Standarisasi Nasioanl tentang persyaratan pakan konsentrat sapi potong (SNI 3148.2:2009) (12\%). Hal ini disebabkan konsentrat dalam penelitian ini mengandung mineral diantaranya $\mathrm{CaCO}_{3}$ dan $\mathrm{NaCl}_{2}$, yang tidak menguap pada waktu pengabuan dalam tanur. Mineral ini diperlukan untuk memenuhi hidup pokok dan pertumbuhan karena mineral terlibat dalam berbagai enzim dan reaksi kimia yang terjadi di dalam jaringan hewan.

\section{Kecernaan Bahan Kering}

Kecernaan bahan kering merupakan salah satu indikator untuk menentukan kualitas ransum. Semakin tinggi kecernaan bahan kering maka semakin tinggi pula peluang nutrisi yang dapat dimanfaatkan ternak untuk pertumbuhannya. Kecernaan bahan kering in vitro menunjukkan proporsi bahan kering ransum yang dapat dicerna oleh mikroba rumen. Kecernaan bahan kering mampu menunjukkan kualitas pakan dan besarnya kemampuan ternak dalam memanfaatkan suatu jenis pakan. Rataan kecernaan bahan kering konsentrat berbahan pakan fermentasi yang diberi penambahan tepung daun sisik naga (Drymoglosum pilloselloides Presl.) secara in vitro dapat dilihat pada Tabel 4.

Tabel 3. Rataan Kecernaan Bahan Kering

\begin{tabular}{cccccc}
\hline \multirow{2}{*}{ Ulangan } & \multicolumn{3}{c}{ Penambahan Tepung Daun Sisik Naga } & \multirow{2}{*}{ Total } \\
\cline { 2 - 5 } & $0 \%(\mathrm{R} 0)$ & $0,05 \%(\mathrm{R} 1)$ & $0,10 \%(\mathrm{R} 2)$ & $0,15 \%(\mathrm{R} 3)$ & \\
\hline 1 & 80.3 & 81.4 & 83.1 & 81.5 & 326.3 \\
\hline 2 & 81.4 & 81.5 & 81.3 & 81.3 & 325.5 \\
\hline 3 & 82.3 & 82.3 & 82.4 & 81.4 & 328.4 \\
\hline Total & 244 & 245.2 & 246.8 & 244.2 & 980.2 \\
\hline Rataan & $81.33 \pm 1,00$ & $81.73 \pm 0,49$ & $82.27 \pm 0,91$ & $81.40 \pm 0,10$ & 81,68 \\
\hline
\end{tabular}

Hasil analisis data menunjukan kecernaan konsentrat berbasis dedak padi fermentasi dengan penambahan tepung daun sisik naga berpengaruh tidak nyata $(\mathrm{P}>0,05 \%)$ terhadap kecernaan bahan kering konsentrat. Hal ini berarti kecernaan bahan kering konsentrat tanpa penambahan tepung daun sisik naga $0 \%$ berbeda tidak nyata dengan kecernaan bahan kering konsentrat dengan penambahan tepung daun sisik naga $0,05 \%, \quad 0,10 \%$ dan $0,15 \% \quad(81,33 \%$ dibanding dengan $81,73 \%, 82,27 \%$ dan $81,40 \%$ ).

Kecernaan bahan kering konsentrat dengan penambahan tepung daun sisik naga $0,05 \%$ berbeda nyata dengan konsentrat dengan penambahan tepung daun sisik naga $0,10 \%$ dan Konsentrat dengan penambahan tepung daun sisik naga $0,15 \% \quad(81,73 \%$ dibanding dengan $82,27 \%$ dan $81,40 \%$ ). Selanjutnya, kecernaan bahan kering konsentrat dengan penambahan tepung daun sisik naga $0,10 \%$ berbeda nyata dengan konsentrat dengan 
penambahan tepung daun sisik naga $0,15 \%$ (82,27\% dibanding dengan $81,40 \%)$. Hal ini menunjukkan penambahan tepung daun sisik naga hingga taraf $0,15 \%$ dalam konsentrat berbahan pakan fermentasi tidak menurunkan kecernaan bahan kering.

Hasil penelitian rataan kecernaan bahan kering konsentrat $(81,68 \%)$ lebih tinggi dibanding dengan hasil penelitian Afriyanti (2008) yang menggunakan ransum dengan penambahan ekstrak bungkil biji jarak pagar (Jatropha curcas L.) dengan nilai kecernaan bahan kering (50-60\%). Selanjutnya hasil penelitian lebih tinggi dibanding dengan hasil penelitian Yuhana $d k k$ (2013) yang menggunakan pakan dengan suplementasi ekstrak herbal berupa ekstrak daging buah lerak (Sapindus rarak) dan ekstrak daging bawang putih (Allium sativum) diperoleh kecernaan bahan kering berkisar (50,25\%-60,05\%). Kecernaan bahan kering hasil penelitian masih dalam kategori normal. Muhtarudin dan Liman (2006) menyatakan semakin tinggi kecernaan bahan kering, semakin meningkat kecernaan bahan organik, dan semakin tinggi peluang nutrisi yang dapat dimanfaatkan ternak untuk produksi.

\section{Kecernaan Bahan Organik}

Kecernaan bahan organik meliputi kecernaan zat-zat makanan berupa komponen bahan organik seperti karbohidrat, protein, lemak dan vitamin. Seperti halnya kecernaan bahan kering, kecernaan bahan organik atau KCBO juga dapat dijadikan tolok ukur dalam menilai kualitas ransum. Nilai KCBK akan sesuai dengan KCBO karena sebagian bahan kering dalam ransum terdiri dari bahan organik (Sutardi, 1980). Rataan kecernaan bahan organik konsentrat berbahan pakan fermentasi yang diberi penambahan tepung daun sisik naga (Drymoglosum pilloselloides Presl.) secara in vitro dapat dilihat pada tabel 5 .

Tabel 4. Rataan Kecernaan Bahan Organik

\begin{tabular}{cccccc}
\hline \multirow{2}{*}{ Ulangan } & \multicolumn{3}{c}{ Penambahan Tepung Daun Sisik Naga } & \multirow{2}{*}{ Total } \\
\cline { 2 - 5 } & $0 \%(\mathrm{R} 0)$ & $0,05 \%(\mathrm{R} 1)$ & $0,10 \%(\mathrm{R} 2)$ & $0,15 \%(\mathrm{R} 3)$ & \\
\hline 1 & 80.5 & 84.5 & 83.1 & 82.1 & 330.2 \\
\hline 2 & 81.5 & 85.1 & 84.1 & 83 & 333.7 \\
\hline 3 & 83.1 & 82.1 & 82.3 & 82.4 & 329.9 \\
\hline Total & 245.1 & 251.7 & 249.5 & 247.5 & 993.8 \\
\hline Rataan & $81.70 \pm 1,31$ & $83.90 \pm 1,59$ & $83.17 \pm 0,90$ & $82.50 \pm 0,46$ & 82,82 \\
\hline
\end{tabular}

Hasil analisis data menunjukan konsentrat dengan penambahan tepung daun sisik naga tidak berpengaruh nyata $(\mathrm{P}>0,05 \%)$ terhadap kecernaan bahan organik konsentrat. Hal ini berarti kecernaan bahan organik konsentrat dengan penambahan tepung daun sisik naga $0 \%$ berbeda tidak nyata dengan kecernaan bahan organik konsentrat dengan penambahan tepung daun sisik naga $0,05 \%$, konsentrat dengan penambahan tepung daun sisik naga $0,10 \%$ dan konsentrat dengan penambahan tepung daun sisik naga $0,15 \%$ (81,70\% dibanding dengan 83,90\%, 83,17\% dan 82,50\%). Kecernaan bahan organik konsentrat dengan penambahan tepung daun sisik naga $0,05 \%$ berbeda tidak nyata dengan konsentrat dengan penambahan tepung daun sisik naga $0,10 \%$ dan konsentrat dengan penambahan tepung daun sisik naga $0,15 \% \quad(83,90 \%$ dibanding dengan $83,17 \%$ dan $82,50 \%$ ). Selanjutnya, kecernaan bahan organik konsentrat dengan penambahan tepung daun sisik naga $0,10 \%$ berbeda nyata dengan konsentrat dengan penambahan tepung 
daun sisik naga $0,15 \%$ (83,17\% dibanding dengan $82,50 \%$ ).

Hasil penelitian rataan kecernaan bahan organik $(82,82 \%)$ lebih tinggi dibanding dengan hasil penelitian penelitian Dewi (2007) yang menggunakan ekstrak bungkil biji jarak dan penelitian Yuhana $d k k$ (2013) yang menggunakan ekstrak herbal berupa ekstrak daging buah lerak (Sapindus rarak) dan ekstrak daging bawang putih (Allium sativum) $(33,62-44,79 \%)$.

\section{KESIMPULAN}

1. Kadar air konsentrat pakan fermentasi dengan penambahan tepung daun sisik naga (Drymoglosum pilloselloides Presl.) (16,58\%) lebih tinggi dari kadar air konsentrat sapi potong yang ditetapkan SNI 3148.2:2009 (14\%).

2. Kadar abu konsentrat pakan fermentasi dengan penambahan tepung daun sisik naga (Drymoglosum pilloselloides Presl.) lebih tinggi $(21,47 \%)$ dari kadar abu konsentrat sapi potong yang ditetapkan SNI 3148.2:2009 (12\%).

3. Rataan kecernaan bahan kering konsentrat pakan fermentasi dengan penambahan tepung daun sisik naga (Drymoglosum pilloselloides Presl.) $(81,68 \%)$ lebih tinggi dari batas minimal kecernaan bahan kering $(50,7 \%)$.

4. Rataan kecernaan bahan organik konsentrat pakan fermentasi dengan penambahan tepung daun sisik naga (Drymoglosum pilloselloides Presl.) $(82,82 \%)$ lebih tinggi dari batas minimal kecernaan bahan organik $(50,7 \%)$.

\section{DAFTAR PUSTAKA}

Abdillah, A. 2006. Aktivitas Antiproliferasi Ekstrak Air Daun Sisik Naga (Drymoglossum pilliselloides) Terhadap Sel Lestari Tumor Hela Secara In
Vitro. Skripsi. IPB. Bogor (Dipublikasikan).

Afriyanti, M., 2008. Fermentabilitas dan Kecernaan In Vitro Ransum yang Diberi Kursin Bungkil Biji Jarak Pagar (Jatropha curcas 1.) Pada ternak sapi dan kerbau. Fakultas Peternakan. IPB. Bogor

Anonim., 2009. Teknologi Pengolahan Pakan Fermentasi [DJP] Direktorat Jenderal Peternakan dan Kesehatan Hewan, Kementrian Pertanian. Jakarta.

Boon, GY. 2006. Penjelasan dan ObatObatan Pakis di Semenanjung. (http://www.pkukmweb.ukm.my/ gohyew.html. Diakses pada tanggal 20 November 2012).

Champagne, E. T. 2004. Rice Chemistry and Technology. $3^{\text {rd }}$ Edition. American Association of Cereal Chemist, Inc. St. Paul, Minnesota, USA. Dalam Sadariawan, G,. 2013. Evaluasi In Vitro Kecernaan Bahan Kering dan Bahan Organik Konsentrat Berbasis Dedak Padi Fermentasi yang Diinokulasi Dengan Mikroba Cairan Rumen. Skripsi. Fakultas Peternakan. Unhalu. Kendari.

Dalimatha, Setiawan. 2006, Atlas Tanaman Obat Indonesia, Jilid I,Cetakan I, Trubus Agriwidya,Jakarta. Hal: 62-64.

Dewi, G. S. 2007. Evaluasi In Vitro Mikroba Rumen Berbagai Ternak Ruminansia Terhadap Pemakaian Bungkil Biji Jarak Pagar (Jatropa curcas L.). Skripsi. Fakultas Peternakan. Institut Pertanian Bogor, Bogor.

Hanifah, 2008. Rancangan Percobaan Teori dan Aplikasi. Raja Grafindo Persada. Jakarta.

Heti, D, 2008. Uji Sitotoksik Ekstrak Etanol $70 \%$ Herba Sisik Naga (Drymoglossum pilliselloides presl.) Terhadap Sel T47D. 
Skripsi. Fakultas Farmasi Universitas Muhamadiyah Surakarta. Solo. (Dipublikasikan).

Hsieh, C. \& F. C. Yang., 2003. Reusing Soy Residue For The Solid-State Fermentation of Ganoderma Lucidum. Bioresource Technol. 80: 21-25. Dalam Nuraini, 2009. Performa Broiler dengan Ransum Mengandung Campuran Ampas Sagu dan Ampas Tahu yang Difermentasi dengan Neurospora crassa. Jurusan Nutrisi dan Makanan Ternak, Fakultas Peternakan, Universitas Andalas Kampus Unand Limau Manis Padang.

Kamra DN. 2005. Special Section Microbial Diversity: Rumen Microbial Ecosystem. Current Sci 89(10): 124-135. Dalam Mizan,. A. B., 2013. Kecernaan In Vitro Bahan Kering dan Bahan Organik Serta Protein Ransum Berbasis Pakan Fermentasi. Skripsi. Fakultas Peternakan. Unhalu. Kendari.

Lee et al., 2002. Distribution and Activities of Hydrolytic Enzymes In The Rumen Compartements Of Hereford Bulls Feed Alfalfa Based Diet. Asian-Aust. J. Anim. Sci. 15(12): 1725 - 1731. Dalam Budiansyah, A. Tasse,A.M., 2011. Hidrolisis Zat Makanan Pakan oleh Enzim Cairan Rumen Sapi Asal Rumah Potong Hewan.Pusat Penelitian Bioteknologi Lembaga Ilmu Pengetahuan Indonesia, Cibinong.

Lopez, S., 2005. In vitro and In situ Techniques for Estimating Digestibility. Dalam J. Dijkstra, J. M. Forbes, and J. France (Eds). Quantitative Aspect for Ruminant Digestion and Metabolism. 2 nd Edition. ISBN 0-85199-8143. CABI Publishing,
London. Dalam Mulyawati. Y., 2009. Fermentabilitas Dan Kecernaan In Vitro Biomineral Dienkapsulasi.

Masruhah, 1. 2008. Pengaruh Penggunaan Limbah Padat Tahu Dalam Ransum Terhadap Konsumsi Pakan, Pertambahan Bobot Badan dan Konversi Pakan Pada Ayam Kampung (Gallus domesticus) Priode Grower. Skripsi. Universitas Islam Negeri. Malang. (Dipublikasikan).

Mizan,. A. B., 2013. Kecernaan In Vitro Bahan Kering dan Bahan Organik Serta Protein Ransum Berbasis Pakan Fermentasi. Skripsi. Fakultas Peternakan. Unhalu. Kendari.

Muhtarudin dan Liman. 2006.

Penentuan Penggunaan Mineral Organik untuk Memperbaiki Bioproses Rumen pada kambing secara In vitro. Jurnal Ilmu-Ilmu Pertanian Indonesia.

Murni, R., Suparto. Akmal, BL. 2008. Buku Ajar Teknologi Pemanfaatan Limbah Untuk Pakan. Laboratorium Makanan Ternak Fakultas Peternakan. Universitas Jambi.

Nurhaya, 2001. Kecernaan Bahan Kering, Serat Kasar, Selulosa dan Hemiselulosa Kayambang (Salvinia molesta) pada itik lokal (http://repository.ipb.ac.id/handle /123456789/12660._ Diakses pada tanggal 25 Maret 2012).

Pasaribu, T., A.P. Sinurat, T. Purwadaria, Supriyati dan H. Hamid., 1998. Peningkatan Nilai Gizi Lumpur Sawit Melalui Proses Fermentasi: Pengaruh Jenis Kapang, Suhu dan Lama Proses Enzimatis. JITV 3(4): 237 242.

Sadariawan, G,. 2013. Evaluasi In Vitro Kecernaan Bahan Kering dan 
Bahan Organik Konsentrat Berbasis Dedak Padi Fermentasi yang Diinokulasi Dengan Mikroba Cairan Rumen. Skripsi. Fakultas Peternakan. Unhalu. Kendari.

Simanjuntak, 2004. Karakteristik Znorganik dan Pengaruh Suplementasinya Terhadap Kecernaan Pakan Serat (In Vitro) Dalam Ransum (http://repository.ipb.ac.id/hand le /123456789/8188 Diakses pada tanggal 25 Maret 2012).

Sulaeman, A., 2001. Produk Mikroba Pakan Langsung (MPL) Kapang dan Pengaruh Terhadap Aktivitas Fermentasi dan Kecernaan Ransum Ruminansia (In Vitro). Program Pascasarjana . IPB. Bogor

Suparyanto, 2003. Pengaruh Pemberian Tepung Ampas Tahu Dalam Ransum Terhadap Produksi Telur Puyuh (Coturnix-coturnix japonica) Umur 20-32 Minggu. Sikripsi. Universitas Bengkulu. Bengkulu. (Dipublikasikan).

SNI 3148.2:2009., 2009. Standar Nasional Indonesia Pakan Sapi Potong. Jakarta.

Steel, R. G. D. dan J. H Torrie. 1993. Prinsip dan Prosedur
Statistika: Suatu Pendekatan Biometrik. Penerjemah : M. Syah. Edisi ketiga. PT Gramedia Pustaka Utama, Jakarta.

Tampoebolon, B.I.M., 2009. Kajian Perbedaan Aras dan Lama Pemeraman Fermentasi Ampas Sagu dengan Aspergillus Niger Terhadap Kandungan Protein Kasar dan Serat Kasar. Prosiding Seminar Nasional Kebangkitan Peternakan Semarang 20 Mei 2009.

Tasse, A.M., 2011. Campuran Garam Karboksilat Dan Metil Ester Kering Sebagai Suplemen Asam Lemak Omega3. Masagena Press. Makassar.

Winarno dan Fardiaz., 1981. Bio Fermentasi dan Bio Sintesa Protein. Angkasa Bandung.

Yuhana., R., Prayitno, C.H., Rustomo., B., 2013. Suplementasi Ekstrak Herbal Dalam Pakan Kambing Perah Pengaruhnya Terhadap Kecernaan Bahan Kering Dan Bahan Organik Serta Konsentrasi VFA Secara In Vitro. Jurnal Ilmiah Peternakan. Fakultas Peternakan. Unsoed. Purwekerto. 